5. International School on Crystallographic Computing Bischenberg (near Strasbourg), 29 July-5 August 1990. Organizing Committee: Dr J. C. Thierry, Laboratoire de Cristallographie Biologique, IBMC, 15, Rue Descartes, 67084 Strasbourg CEDEX, France.

Programme Committee: Dr D. Moras.

Acta Cryst. (1989). A45, 148

\section{Report on the IUCr Logo Design Contest}

A total of 165 designs sent in by 68 entrants from 21 different countries (see Table 1) were received by the IUCr Logo Committee as entries for the Logo Design Contest [Acta Cryst. (1988), A44, 231-232]. The Committee reached the final conclusion on Sunday 28 August 1988 in Vienna, prior to the Eleventh European Crystallographic Meeting. The sealed envelope containing the name of the winner was

Table 1. Entrants to logo competition

$\begin{array}{lcc}\text { Country } & \text { Number of entrants } & \text { Number of entries } \\ \text { China PR } & 1 & 1 \\ \text { Czechoslovakia } & 2 & 7 \\ \text { Denmark } & 1 & 3 \\ \text { France } & 1 & 3 \\ \text { Germany DR } & 3 & 9 \\ \text { Germany FR } & 1 & 1 \\ \text { Hungary } & 7 & 18 \\ \text { Iran } & 1 & 3 \\ \text { Israel } & 1 & 2 \\ \text { Italy } & 7 & 18 \\ \text { Mexico } & 1 & 2 \\ \text { Netherlands } & 4 & 8 \\ \text { Philippines } & 1 & 3 \\ \text { Poland } & 7 & 19 \\ \text { South Africa } & 1 & 2 \\ \text { Spain } & 1 & 1 \\ \text { Sweden } & 2 & 6 \\ \text { Switzerland } & 4 & 7 \\ \text { UK } & 8 & 23 \\ \text { USA } & 13 & 28 \\ \text { Yugoslavia } & 1 & 1 \\ & 68 & 165\end{array}$

opened in the presence of the President of the IUCr, Professor M. Nardelli, and another member of the Executive Committee, Dr E. N. Maslen. The winning entry was designed by:

Professor Giovanni Predieri

Istituto di Chimica Generale ed Inorganica

Università di Parma

Italy

Mrs Susanna Ciribolla

Centro Grafico

Università di Parma

Italy.

The final design of the IUCr logo will be published in the Union's journals after some small adjustments have been made to the winning submission.

Acta Cryst. (1989). A45, 148

\section{Books Received}

The following books have been received by the Editor. Brief and generally uncritical notices are given of works of marginal crystallographic interest; occasionally a book of fundamental interest is included under this heading because of difficulty in finding a suitable reviewer without delay.

Organic solid state chemistry. (Vol. 32 of Studies in organic chemistry.) Edited by G. R. Desiraju. Pp. xii +550. Amsterdam: Elsevier Science Publishers, 1987. Price Dfl 360 or US $\$ 175.50$. A review of this book, by K. J. McCullough, has been published in the October 1988 issue of Journal of Applied Crystallography, page 580.

Mineralogie. By SiEgfRIEd MAtThes. Pp. xvii + 444. Berlin: Springer-Verlag, 1987. Price DM 69. A review of this book, by J. E. Chisholm, has been published in the December 1988 issue of Journal of Applied Crystallography, page 996. 